UDC 577

\title{
Lamina-associated chromatin in the context of the mammalian genome folding
}

\author{
S. V. Ulianov ${ }^{1,2}$, Y. Y. Shevelyov³, S. V. Razin ${ }^{1,2}$ \\ ${ }^{1}$ Institute of Gene Biology, Russian Academy of Sciences \\ 34/5, Vavilova Str., Moscow, Russian Federation, 119334 \\ ${ }^{2}$ Faculty of Biology, M. V. Lomonosov Moscow State University \\ Leninskie Gory, Moscow, Russian Federation, 119991 \\ ${ }^{3}$ Institute of Molecular Genetics RAS, \\ 2, Kurchatova sq., Moscow, Russian Federation, 123182 \\ sergey.v.razin@usa.net
}

\begin{abstract}
Eukaryotic interphase chromatin is folded hierarchically. Mammalian chromosomes are partitioned into topologically associating domains (TADs) whose interactions with each other drive the spatial segregation of the bulk chromatin into A-compartment containing active genomic regions, and B-compartment harboring repressed genomic loci and gene deserts. The internal structure of TADs is represented by CTCF/cohesin-mediated loops. The specific local and large-scale spatial structure of chromosomes plays an important role in the regulation of the genome functions. The recruiting of the genome loci to internal nuclear structures drives a subset of long-range chromatin interactions. The nuclear lamina is found to be involved into chromatin spatial positioning within the nucleus. The chromatin-nuclear lamina interactions are not rigid allowing for a substantial reconfiguration of the genome topology in cell generations and during differentiation. Here, we review some resent findings shedding light on the nature and spatial dynamics of the lamina-associated genomic regions.
\end{abstract}

Ke y w o r d s: nuclear lamina, chromatin compartments, TADs, loops, CTCF

\section{Introduction}

The entire nuclear space in mammals is substantially compartmentalized [1]. Chromosomes occupy distinct territories, whose internal structure is spatially organized at multiple levels. Local and long-range contacts between genomic regions are driven by stochastic motion of chromatin fiber, specific associations of functionally related gene loci, direct protein-protein interactions resulting in loop formation, and by the co-occurrence of remote chromosomal segments within nuclear bodies and specific nuclear structures [2]. At the whole-chromosome level, mammalian chromatin is partitioned into predomi- nantly active and generally repressed compartments, formed by long-range interactions of topologically associating domains (TADs) whose formation, in turn, appears to be driven by the looping between $\mathrm{CTCF} /$ cohesin-occupied regions [3].

The nuclear lamina (NL) is the largest structure inside the nucleus. The NL represents a fibrillary protein layer adjacent to inner nuclear membrane and composed of several types of lamins and laminassociated proteins. Components of the NL were found to be directly bound to chromatin and chromatin-associated regulatory factors. In mammals, about $30-40 \%$ of the genome interact with the nuclear lamina [4]. Constitutive lamina-associated regions

(C) 2016 S. V. Ulianov et al.; Published by the Institute of Molecular Biology and Genetics, NAS of Ukraine on behalf of Biopolymers and Cell. This is an Open Access article distributed under the terms of the Creative Commons Attribution License (http://creativecommons.org/licenses/by/4.0/), which permits unrestricted reuse, distribution, and reproduction in any medium, provided the original work is properly cited 
of the genome (LADs) are typically gene-poor and AT-rich inactive genomic regions ranged between 0.1 and $10 \mathrm{Mb}$ in size and are characterized by high level of H3K9 mono-, di- and three-methylation along with the Polycomb-associated repressive mark H3K27me3 [4, 5]. A large cohort of studies performed using fluorescence in situ hybridization and various biochemical techniques have revealed that the nuclear periphery in a vicinity of the NL represents generally inactive nuclear compartment and accumulates gene loci undergoing transcriptional repression during development and differentiation [6]. A number of reports on the role of the nuclear lamina in the genome folding were published in last few years. Here, we briefly review several recent advances in understanding the chromatin spatial organization and its relationships with the chromatin recruiting to the nuclear lamina.

\section{The overall scheme of the chromatin spatial organization in mammals}

Recent progress in the exploration of the animal genome spatial structure achieved using various highthroughput 3C-based techniques such as $4 \mathrm{C}, 5 \mathrm{C}$, $\mathrm{Hi}-\mathrm{C}$ and capture- $\mathrm{C}$ [7] has revealed a complex pattern of local and long-distance spatial interactions within the interphase chromatin, and the basic principles of the genome folding were disclosed $[1,8]$. At the whole-genome level, the spatial clustering of small chromosomes and large chromosomes with each other was observed in human cells [9] (Fig. 1A). These data corroborate classical cytological observations and the results of fluorescence in situ hybridization showing that chromosomes occupy distinct, largely non-overlapped chromosome territories within the eukaryotic cell nucleus, and that small gene-rich chromosomes are typically located within the central part of the nucleus whereas large chromosomes are located at the nuclear periphery [10].

At the chromosomal level, the interphase chromatin in mammals is partitioned into $\mathrm{A}$ and $\mathrm{B}$ chromatin compartments [9] (Fig. 1B). The A-compartment is formed by pairwise long-range (up to throughout the entire chromosome) interactions of gene-dense highly transcribed regions enriched with a broad pattern of active epigenetic marks. Interacting partners could be single TADs (see below) or arrays of TADs having a length up to dozens of megabases. In contrast, the B-compartment is formed by long-range interactions of inactive parts of the genome and gene deserts. The chromatin compartment profile is considerably variable among different cell types. During differentiation of the human embryonic stem cells (ESC) a large reconfiguration of chromatin compartments and an expansion of the B-compartment were observed [11]. Genes that were upregulated upon differentiation were preferentially transferred from $\mathrm{B}$ to A compartment, whereas downregulated genes predominantly changed the compartment from A to B. Global reorganization of chromatin compartments was also observed in senescent cells $[12,13]$. Hence, the chromatin compartment profile reflects the functional state of the genome.

Increase of a $\mathrm{Hi}-\mathrm{C}$ map resolution to approximately $50 \mathrm{~Kb}$ has revealed the presence of self-interacting regions $100-1000 \mathrm{~Kb}$ in length located side by side along the chromosome and interacting with each other relatively weak[ly] [14, 15] (Fig. 1C). Such regions were initially called topologically associating domains (TADs), or contact domains (CDs), and are commonly interpreted as chromatin globules. TADs have a typical size of $100-1000 \mathrm{~Kb}$ in mammals and about 50-200 Kb in Drosophila $[14,16,17]$. Mammalian TAD boundaries are enriched with housekeeping and tRNA genes, SINE repetitive elements and CTCF-binding sites [14]. In Drosophila, TADs harbor predominantly repressed genomic regions whereas TAD boundaries and inter-TADs contain active genes (predominantly housekeeping) $[17,18]$. TAD boundaries in mammals possess prominent enhancer-blocking activity. It has been shown that communication via chromatin loop formation between enhancers and target promoters typically occurs within the same TAD [19], and TADs colocalize with the so-called "regulatory" domains that delimit zones of enhancer influence [20]. Thus, in terms of function, mammalian TADs represent the transcription regulatory units of the ge- 


\section{Schematic representation}

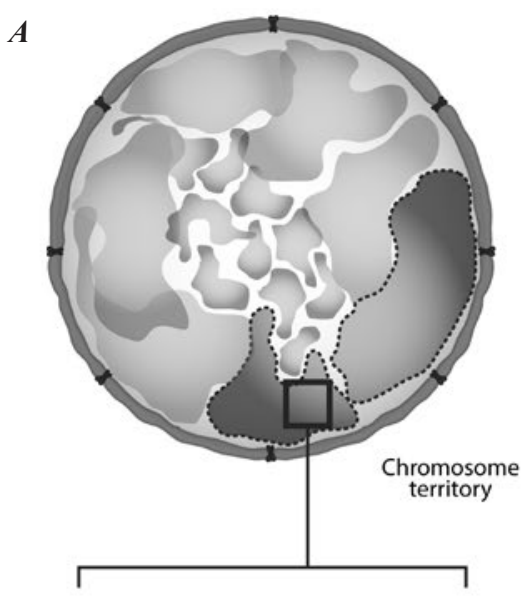

B

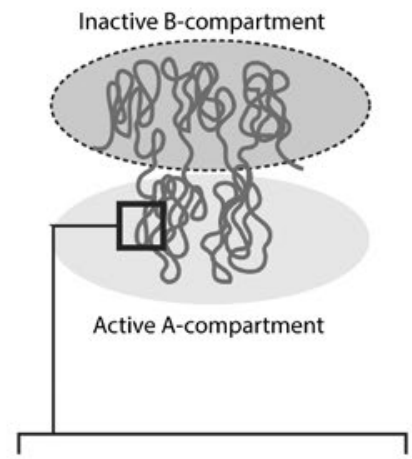

C

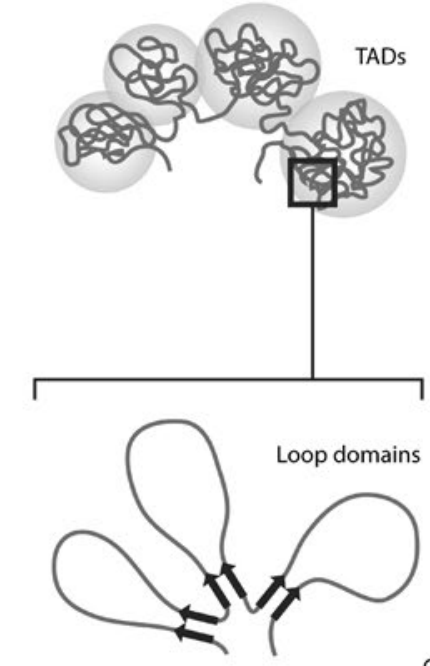

\section{Illustrative $\mathrm{Hi}-\mathrm{C}$ maps}
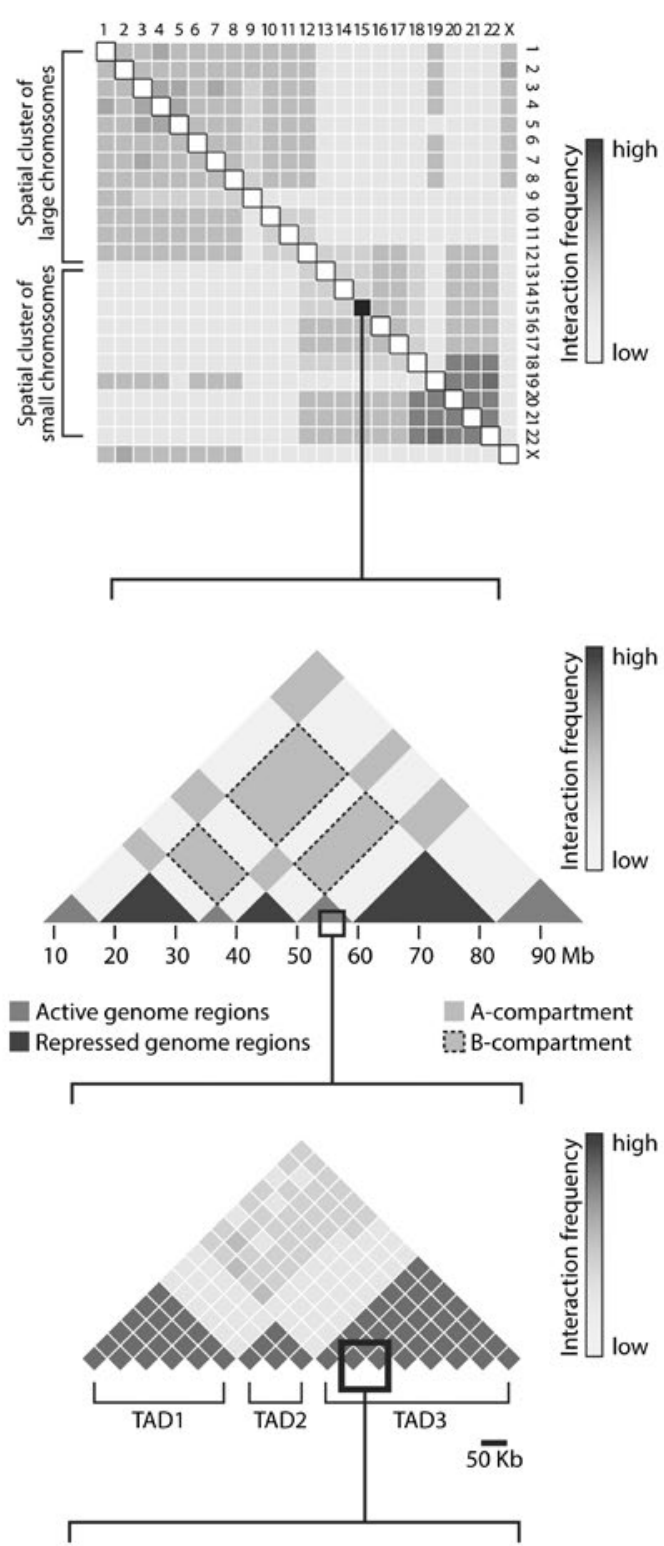

CTCF-binding site

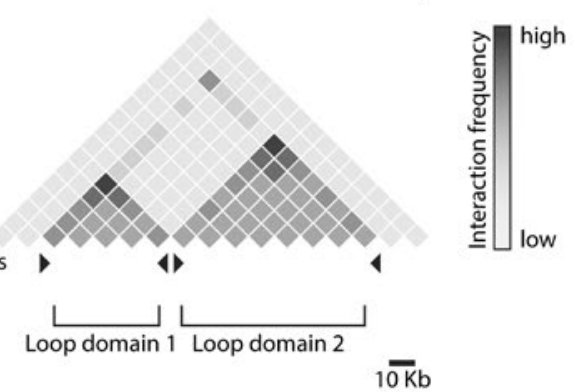

Fig. 1. A schematic representation of the mammalian chromatin spatial organization at different levels, and corresponding illustrative Hi-C maps. A Chromosomes occupy distinct territories within cell nucleus. Large chromosomes are typically located at the nuclear periphery, and small ones are deposited within the nuclear interior that is manifested in the enrichment of $\mathrm{Hi}-\mathrm{C}$-captured contacts within clusters of large and small chromosomes. In the illustrative Hi-C map, shown on the left panel, color intensity represents interaction frequency between the whole chromosomes. $B$-Active and repressed chromosome regions are largely segregated from each other within the chromosome territory forming active $\mathrm{A}-$ and repressed B-compartment. Color intensity on the illustrative $\mathrm{Hi}-\mathrm{C}$ represents interaction frequency within chromatin compartments between extended regions of the chromosome. $C-$ At megabase- and submegabase-scale, chromatin is partitioned into self-interacting topologically associating domains (TADs) commonly interpreted as chromatin globules. Color intensity on the illustrative $\mathrm{Hi}-\mathrm{C}$ represents interaction frequency between $50 \mathrm{~Kb}$ genomic bins. $D$ - Inside TADs, CTCF-binding sites interact with each other forming loop domains ranged between $\sim 20-$ $200 \mathrm{~Kb}$ in size. These loops often bring enhancers and promoters together providing positive transcription regulation. Color intensity on the illustrative $\mathrm{Hi}-\mathrm{C}$ represents interaction frequency between $10 \mathrm{~Kb}$ genomic bins. 
nome. Although TAD boundaries are critical genomic elements preventing abnormal enhancer-promoter communication [21], they do not completely insulate TADs from each other: contact frequency between adjacent TADs is only about 2 fold lower than the intra-TAD contact frequency [1].

The further increase of the $\mathrm{Hi}-\mathrm{C}$ maps resolution up to $1 \mathrm{~Kb}$ allowed revealing the abundant presence of CTCF-anchored chromatin loops forming the socalled "loop domains" with a median size of $185 \mathrm{~Kb}$ located inside the megabase-sized TADs [22] (Fig. 1D). Approximately 10000 such loops were found in the human genome. About $30 \%$ of these loops bring the promoters and enhancers together, and genes associated with the loops are expressed at significantly higher level than the genes whose promoters are not involved into looping interactions. Interestingly, according to different estimations, 60$90 \%$ of loops $[22,23]$ are formed between convergent CTCF binding sites that hints the possible mechanism of loop formation based on CTCF protein structural features. The recently proposed model of DNA loop extrusion successfully explains the observed Hi-C data [24-26]. However, the molecular machine that actually performs the extrusion (and consequently provides enhancer-promoter communication) is currently not found. The main candidates are RNA-polymerase II and the condensin complex $[26,27]$. Along with loop domains, the so-called "ordinary" domains were also observed. Despite the fact [that] the formation of these domains could not be explained directly by loop extrusion, the indirect mechanism could be suggested: the genomic region located between two loop domains is spatially segregated from them that may lead to the increased contact frequency inside this region as compared to its contact frequency with the flanking loop domains. Thus, $\mathrm{CTCF} /$ cohesin-anchored loops represent the basic level of the large-scale chromatin topology in mammals and are directly involved into long-range transcriptional regulation. Interestingly, CTCF-anchored loops are not robustly detected in the Drosophila genome, and TAD boundaries in Drosophila are not considerably enriched with CTCF binding sites [18].
It denotes that mechanisms of TAD formation may be different in mammals and insects. Recently, we have proposed a model implementing internucleosomal interactions of non-acetylated repressed chromatin (predominantly deposited within TADs in Drosophila) as the driving force for the TAD formation and maintenance in Drosophila [18]. Notably, the same mechanism could be responsible for the compaction of the extrusion-driven loops into globular structures in mammalian genomes.

\section{The role of the nuclear lamina in chromatin spatial organization}

A considerable portion of the mammalian genome (about 30-40 \%) is associated with the nuclear lamina [4]. The mechanical aspects of chromatin tethering to the NL are not fully understood, but there are at least two models [28]: zipping structure and pointed anchors. According to the first model, the whole LAD is recruited to the NL that is supported by the observation that large LADs are typically attached to the NL via long contact runs. The second model postulates the existence of a limited number of anchor points within a LAD that cooperatively provide LAD attachment to the NL. The main candidates on the role of such anchors are binding sites for transcriptional repressors [29-31]. However, in the both models, H3K9 and H3K27 methylation appear to be crucial for the LAD deposition at the NL, because the readers for these epigenetic marks are located within or are recruited to the lamina [32].

There are several controversial reports on the role of nuclear lamina in the maintenance of the interphase chromatin structure in mammals. Human fibroblasts expressing dominant-negative form of Lamin-A (progerin) demonstrate a considerable loss of spatial compartmentalization of active and inactive genome regions as revealed by $\mathrm{Hi}-\mathrm{C}$ analysis, [an] altered pattern of $\mathrm{H} 3 \mathrm{~K} 27 \mathrm{me} 3$ distribution and substantial changes of gene expression [33]. Microscopic studies have revealed that the loss of Lamin-B1 in mouse fibroblasts results in relocation of a gene-poor chromosome 18 from the lamina to the nuclear interior [34], and in a human colon can- 
cer cell line Lamin-B1 deficiency leads to decondensation of chromosome territories [35]. On the other hand, it has been shown that double knockdown of Lamin B1/B2 virtually does not affect the LAD profile and gene expression in mouse ESC [36]. To this end, some other proteins localized within inner nuclear membrane could be responsible for the chromatin positioning at nuclear periphery. The most likely candidates are Lamin-B receptor (LBR) and LEM-proteins such as EMD which were found to interact with chromatin in vivo [37-39].

\section{LAD dynamics: lessons from single-cell studies}

Dynamic interactions between the nuclear lamina (NL) and interphase chromatin were extensively studied in Bas van Steensel's laboratory. The first clear evidence for highly dynamic nature of the NLchromatin contacts has been obtained using the ${ }^{\mathrm{m} 6} \mathrm{~A}-$ Tracer technology based on the expression of the fusion of GFP protein with the DpnI restriction enzyme recognizing methylated adenine in GATC context [40]. As adenine-6-methylation is a stable covalent modification, it is inheritable in cell generations allowing one to track the fate of LADs throughout the cell cycle and after cell division in a living cell expressing lamin fused with bacterial Dam-methylase (the enzyme used in DamID technology to methylate adenine in GATC context). It has been shown that chromatin attached to the nuclear lamina possesses remarkably constrained mobility and generally does not migrate to the nuclear interior during interphase. However, LADs stochastically reshuffle after mitosis and some of them could be found in a vicinity of nucleoli in daughter cells. The next breakthrough technology providing the further progress in understanding the NL-chromatin interaction mechanisms and dynamics is a recently developed single-cell DamID approach [41]. The current version of this method is suitable for studying the NL-chromatin contacts in single cells at a resolution of $100 \mathrm{~Kb}$. The results obtained indicate that about $15 \%$ of the genome composed of constitutive gene-poor LADs associates with the NL in the majority of cells. This finding sug- gests the presence of a "scaffold" structure presumably involved in the overall shaping of the chromosome spatial configuration. In contrast, about $30 \%$ of the genome exhibit a high cell-to-cell variability in the interaction with the nuclear lamina. Interestingly, distantly located loci often establish the contacts with the nuclear lamina in a coordinated manner. Furthermore, it was found that at distances up to $20 \mathrm{Mb}$ the $\mathrm{Hi}-\mathrm{C}$ profile moderately correlates with the degree of $\mathrm{NL}$-chromatin contacts. It is tempting to assume that spatial interactions of remote genomic regions with each other may direct the coordinated recruitment of functionally-related loci to the nuclear lamina and thus provide coordinated gene repression.

\section{Concluding remarks}

In sum, the nuclear lamina plays a remarkable role in the genome folding and regulation. The further understanding of the mechanisms involved into chromatin tethering to the nuclear lamina could be considerably improved by applying new microscopic and biochemical techniques such as super-resolution live-cell imaging and combination of singlecell DamID technique with $\mathrm{Hi}-\mathrm{C}$ analysis of chromatin configuration in the same cell.

\section{Acknowledgments}

This study was supported by the Russian Science Foundation (project 16-14-10081).

\section{REFERENCES}

1. Dekker J, Mirny L. The 3D Genome as Moderator of Chromosomal Communication. Cell. 2016;164(6):1110-21.

2. Ulianov SV, Gavrilov AA, Razin SV. Nuclear compartments, genome folding, and enhancer-promoter communication. Int Rev Cell Mol Biol. 2015;315:183-244.

3. Dekker J, Heard E. Structural and functional diversity of Topologically Associating Domains. FEBS Lett. 2015;589 (20 Pt A):2877-84.

4. Guelen L, Pagie L, Brasset E, Meuleman W, Faza MB, Talhout W, Eussen BH, de Klein A, Wessels L, de Laat W, van Steensel B. Domain organization of human chromosomes revealed by mapping of nuclear lamina interactions. Nature. 2008;453(7197):948-51.

5. Peric-Hupkes D, Meuleman W, Pagie L, Bruggeman SW, Solovei I, Brugman W, GräfS, Flicek P, Kerkhoven RM, van 
Lohuizen M, Reinders M, Wessels L, van Steensel B. Molecular maps of the reorganization of genome-nuclear lamina interactions during differentiation. Mol Cell. 2010;38(4): 603-13.

6. Towbin BD, Meister P, Gasser SM. The nuclear envelope-a scaffold for silencing? Curr Opin Genet Dev. 2009;19(2): 180-6.

7. Denker $A$, de Laat $W$. The second decade of $3 \mathrm{C}$ technologies: detailed insights into nuclear organization. Genes Dev. 2016;30(12):1357-82.

8. Gavrilov AA, Shevelyov YY, Ulianov SV, Khrameeva EE, Kos $P$, Chertovich A, Razin SV. Unraveling the mechanisms of chromatin fibril packaging. Nucleus. 2016;7(3):319-24.

9. Lieberman-Aiden E, van Berkum NL, Williams L, Imakaev M, Ragoczy T, Telling A, Amit I, Lajoie BR, Sabo PJ, Dorschner MO, Sandstrom R, Bernstein B, Bender MA, Groudine M, Gnirke A, Stamatoyannopoulos J, Mirny LA, Lander ES, Dekker J. Comprehensive mapping of longrange interactions reveals folding principles of the human genome. Science. 2009;326(5950):289-93.

10. Cremer T, Cremer M. Chromosome territories. Cold Spring Harb Perspect Biol. 2010;2(3):a003889.

11. Dixon JR, Jung I, Selvaraj S, Shen Y, Antosiewicz-Bourget JE, Lee AY, Ye Z, Kim A, Rajagopal N, Xie W, Diao Y, Liang J, Zhao H, Lobanenkov VV, Ecker JR, Thomson JA, Ren $B$. Chromatin architecture reorganization during stem cell differentiation. Nature. 2015;518(7539):331-6.

12. Chandra T, Ewels PA, Schoenfelder S, Furlan-Magaril M, Wingett SW, Kirschner K, Thuret JY, Andrews S, Fraser P, Reik $W$. Global reorganization of the nuclear landscape in senescent cells. Cell Rep. 2015;10(4):471-83.

13. Criscione $S W$, De Cecco M, Siranosian B, Zhang Y, Kreiling JA, Sedivy JM, Neretti N. Reorganization of chromosome architecture in replicative cellular senescence. Sci Adv. 2016;2(2):e1500882.

14. Dixon JR, Selvaraj S, Yue F, Kim A, Li Y, Shen Y, Hu M, Liu JS, Ren B. Topological domains in mammalian genomes identified by analysis of chromatin interactions. Nature. 2012;485(7398):376-80.

15. Nora EP, Lajoie BR, Schulz EG, Giorgetti L, Okamoto I, Servant N, Piolot T, van Berkum NL, Meisig J, Sedat J, Gribnau J, Barillot E, Blüthgen N, Dekker J, Heard E. Spatial partitioning of the regulatory landscape of the $\mathrm{X}$-inactivation centre. Nature. 2012;485(7398):381-5.

16. Sexton T, Yaffe E, Kenigsberg E, Bantignies F, Leblanc B, Hoichman M, Parrinello H, Tanay A, Cavalli G. Three-dimensional folding and functional organization principles of the Drosophila genome. Cell. 2012;148(3):458-72.

17. Hou C, Corces VG. Throwing transcription for a loop: expression of the genome in the $3 \mathrm{D}$ nucleus. Chromosoma. 2012;121(2):107-16.

18. Ulianov SV, Khrameeva EE, Gavrilov AA, Flyamer IM, Kos P, Mikhaleva EA, Penin AA, Logacheva MD, Imakaev
MV, Chertovich A, Gelfand MS, Shevelyov YY, Razin SV. Active chromatin and transcription play a key role in chromosome partitioning into topologically associating domains. Genome Res. 2016;26(1):70-84.

19. Jin F, Li Y, Dixon JR, Selvaraj S, Ye Z, Lee AY, Yen CA, Schmitt AD, Espinoza $C A$, Ren B. A high-resolution map of the three-dimensional chromatin interactome in human cells. Nature. 2013;503(7475):290-4.

20. Symmons O, Uslu VV, Tsujimura T, Ruf S, Nassari S, Schwarzer W, Ettwiller L, Spitz F. Functional and topological characteristics of mammalian regulatory domains. Genome Res. 2014;24(3):390-400.

21. Lupiáñez DG, Spielmann M, Mundlos S. Breaking TADs: How Alterations of Chromatin Domains Result in Disease. Trends Genet. 2016;32(4):225-37.

22. Rao SS, Huntley MH, Durand NC, Stamenova EK, Bochkov ID, Robinson JT, Sanborn AL, Machol I, Omer AD, Lander ES, Aiden EL. A 3D map of the human genome at kilobase resolution reveals principles of chromatin looping. Cell. 2014;159(7):1665-80.

23. Mumbach MR, Rubin AJ, Flynn RA, Dai C, Khavari PA, Greenleaf WJ, Chang HY. HiChIP: efficient and sensitive analysis of protein-directed genome architecture. Nat Methods. 2016;13(11):919-922.

24. Sanborn AL, Rao SS, Huang SC, Durand NC, Huntley MH, Jewett AI, Bochkov ID, Chinnappan D, Cutkosky A, Li J, Geeting KP, Gnirke A, Melnikov A, McKenna D, Stamenova EK, Lander ES, Aiden EL. Chromatin extrusion explains key features of loop and domain formation in wild-type and engineered genomes. Proc Natl Acad Sci US A. 2015; 112(47):E6456-65.

25. Goloborodko A, Marko JF, Mirny LA. Chromosome Compaction by Active Loop Extrusion. Biophys J. 2016;110(10): 2162-8.

26. Fudenberg G, Imakaev M, Lu C, Goloborodko A, Abdennur $N$, Mirny LA. Formation of Chromosomal Domains by Loop Extrusion. Cell Rep. 2016;15(9):2038-49.

27. Razin SV, Gavrilov AA, Vassetzky YS, Ulianov SV. Topologically-associating domains: gene warehouses adapted to serve transcriptional regulation. Transcription. 2016;7(3):84-90.

28. Pueschel $R$, Coraggio F, Meister P. From single genes to entire genomes: the search for a function of nuclear organization. Development. 2016;143(6):910-23.

29. Zullo JM, Demarco IA, Piqué-Regi R, Gaffney DJ, Epstein CB, Spooner CJ, Luperchio TR, Bernstein BE, Pritchard JK, Reddy KL, Singh H. DNA sequence-dependent compartmentalization and silencing of chromatin at the nuclear lamina. Cell. 2012;149(7):1474-87.

30. Bian Q, Khanna N, Alvikas J, Belmont AS. $\beta-$ Globin ciselements determine differential nuclear targeting through epigenetic modifications. J Cell Biol. 2013;203(5):767-83.

31. Harr JC, Luperchio TR, Wong X, Cohen E, Wheelan SJ, Reddy KL. Directed targeting of chromatin to the nuclear 
lamina is mediated by chromatin state and A-type lamins. $J$ Cell Biol. 2015;208(1):33-52.

32. Harr JC, Gonzalez-Sandoval A, Gasser SM. Histones and histone modifications in perinuclear chromatin anchoring: from yeast to man. EMBO Rep. 2016;17(2):139-55.

33. McCord RP, Nazario-Toole A, Zhang H, Chines PS, Zhan Y, Erdos MR, Collins FS, Dekker J, Cao K. Correlated alterations in genome organization, histone methylation, and DNA-lamin A/C interactions in Hutchinson-Gilford progeria syndrome. Genome Res. 2013;23(2):260-9.

34. Malhas A, Lee CF, Sanders R, Saunders NJ, Vaux DJ. Defects in lamin B1 expression or processing affect interphase chromosome position and gene expression. J Cell Biol. 2007;176(5):593-603.

35. Camps J, Wangsa D, Falke M, Brown M, Case CM, Erdos MR, Ried T. Loss of lamin B1 results in prolongation of $\mathrm{S}$ phase and decondensation of chromosome territories. FASEB J. 2014;28(8):3423-34.

36. Amendola $M$, van Steensel $B$. Nuclear lamins are not required for lamina-associated domain organization in mouse embryonic stem cells. EMBO Rep. 2015;16(5):610-7. PubMed Central

37. Makatsori D, Kourmouli N, Polioudaki H, Shultz LD, McLean K, Theodoropoulos PA, Singh PB, Georgatos SD. The inner nuclear membrane protein lamin $B$ receptor forms distinct microdomains and links epigenetically marked chromatin to the nuclear envelope. $J$ Biol Chem. 2004;279(24):25567-73.

38. Ye Q, Callebaut I, Pezhman A, Courvalin JC, Worman HJ. Domain-specific interactions of human HP1-type chromodomain proteins and inner nuclear membrane protein LBR. J Biol Chem. 1997;272(23):14983-9.

39. Berk JM, Tifft KE, Wilson KL. The nuclear envelope LEMdomain protein emerin. Nucleus. 2013;4(4):298-314.

40. Kind J, Pagie L, Ortabozkoyun H, Boyle S, de Vries SS, Janssen H, Amendola M, Nolen LD, Bickmore WA, van Steensel $B$. Single-cell dynamics of genome-nuclear lamina interactions. Cell. 2013;153(1):178-92.

41. Kind J, Pagie L, de Vries SS, Nahidiazar L, Dey SS, Bienko M, Zhan Y, Lajoie B, de Graaf CA, Amendola M, Fudenberg $G$, Imakaev M, Mirny LA, Jalink K, Dekker J, van Oudenaarden A, van Steensel B. Genome-wide maps of nuclear lamina interactions in single human cells. Cell. 2015;163(1):134-47.

\section{Хроматин асоційований $з$ ламінами в контексті просторової структури генома ссавців}

С. В. Ульянов, Ю. Я. Шевельов, С. В. Разін

Інтерфазна хроматин еукаріот характеризується ієрархічної просторовою структурою. Хромосоми ссавців розділені на топологічно асоційовані домени (тади), взаємодії яких один з одним визначають наявність хроматінових компартментов двох типів, один 3 яких (А-компартмент) містить активні ділянки геному, а другий - репресовані райони і генні пустелі (В-компартмент). Внутрішня структура ТАДов представлена головним чином хроматиновими петлями між ділянками зв'язування білка СТCF і когезіна. Специфічна побутовій та іншій великомасштабна просторова організація хроматину грає важливу роль в регуляції роботи генома. Частина дистанційних взаємодій в хроматині визначається залученням різних районів геному до внутрішніх структур ядра. Ядерна ламина бере участь у встановленні та підтримці просторової структури хроматину. Взаємодії хроматину з ядерної Ламін $є$ значною мірою динамічними, що обумовлює можливість перебудови тривимірної архітектури хроматину в ряді клітинних поколінь і в процесі диференціювання. У даній оглядовій статті ми сфокусували увагу на ряді недавно отриманих експериментальних даних, що стосуються природи і динаміки взаємодій хроматину з ядерної Ламін.

Кл юч о в і с л ов а: ядерна ламина, структури хроматину, ТАД, петлі, СТСF.

\section{Ламина-ассоциированный хроматин в контексте пространсвенной структуры генома млекопитающих}

\section{С. В. Ульянов, Ю. Я. Шевелёв, С. В. Разин}

Интерфазный хроматин эукариот характеризуется иерархической пространственной структурой. Хромосомы млекопитающих разделены на топологически ассоциированные домены (ТАДы), взаимодействия которых друг с другом определяют наличие хроматиновых компартментов двух типов, один их которых (А-компартмент) содержит активные участки генома, а второй - репрессированные районы и генные пустыни (В-компартмент). Внутренняя структура ТАДов представлена главным образом хроматиновыми петлями между участками связывания белка СТCF и когезина. Специфическая локальная и крупномасштабная пространственная организация хроматина играет важную роль в регуляции работы генома. Часть дистанционных взаимодействий в хроматине определяется привлечением разных районов генома к внутренним структурам ядра. Ядерная ламина участвует в установлении и поддержании пространственной структуры хроматина. Взаимодействия хроматина с ядерной ламиной являются в значительной мере динамичными, что обуславливает возможность перестройки трёхмерной архитектуры хроматина в ряду клеточных поколений и в процессе дифференцировки. В данной обзорной статье мы сфокусировали внимание на ряде недавно полученных экспериментальных данных, касающихся природы и динамики взаимодействий хроматина с ядерной ламиной.

Кл юч е в ы с сл о а: ядерная ламина, структуры хроматина,ТАД, петли, СТCF

Received 08.08.2016 